\title{
Situation Analysis of Tuberculosis to Accelerate the Role of All Regional Stakeholders in Kendal
}

\author{
Tri Hartiti* (D), Amin Samiasih, Siti Asiah, Ernawati Ernawati, Dera Alfiyanti \\ Department of Nursing, Faculty of Nursing and Health Sciences, Universitas Muhammadiyah Semarang, Semarang, Indonesia
}

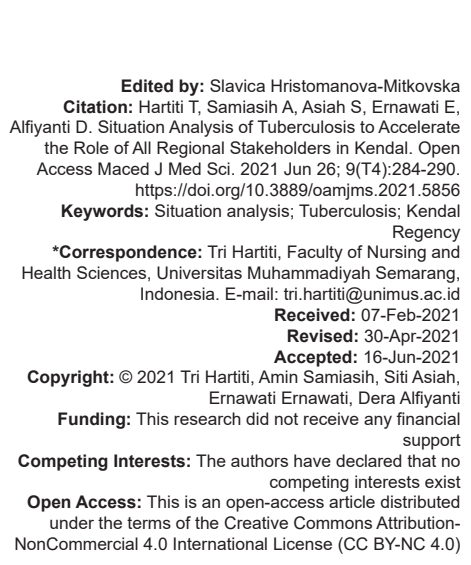

\section{Introduction}

Indonesia is in fourth place among the countries with the highest TB patient, such as India, China, and South Africa. It is estimated that the TB patient in Indonesia is $10 \%$ of the total number of TB patients in the world. The Millennium Development Goals (MDGs) are expected to decrease half of the TB patients by 2015. However, the current situation was far from expectation, as 1464 people in a day, ten people in an hour, and one person every 6 min die from TB (Ethical Digest, 2008) [1]. Therefore, started in 1995, the WHO recommended a tuberculosis (TB) control national program by implementing the Directly Observed Treatments Short Course (DOTS) strategy. Therefore, since 2000, the DOTS strategy was nationally implemented in every health-care unit, especially the community health center, which is integrated with basic healthcare to reach MDGs [2,3].

Besides the TB problem mentioned above, there was another problem: Multidrug-resistant tuberculosis (MDR-TB) or the resistance toward multidrug such as rifampicin and isoniazid with or without other antituberculosis drugs HIV-TB as the effect of
HIV AIDS growth in Indonesia [4,5]. MDR-TB existed in Indonesia and even showed significant secondary and primary resistance patterns at some referral centers. However, the MDR-TB prevalence in the community was unidentifiable. However, it considerably lowers. The MDR-TB prevalence in Indonesia was 700 cases, and the HIV-TB was 3511 cases. The achievement of CDR in central java during 2008-2012 was under the target of $100 \%$. However, it was under the target, the CDR achievement in 2012 was $58.45 \%$, which was lower than that of 2011 with $59.52 \%$. The highest CDR was at Kota Magelang with $292.91 \%$, and the lowest was at Magelang Regency, with $21.82 \%$. There were five regencies which passed the $100 \%$ target (Profile Kesehatan Provinsi Jawa Tengah tahun 2012). They were Kota Magelang (292.91\%), Kota Surakarta (128.17\%), Kota Salatiga (109.84\%), Kota Tegal (203.09\%), and Kota Pekalongan (137.75\%). Meanwhile, Kendal regency, there were $28.5 \%$ TB cases with the recovery rate reached 90.8 [6].

The Regional Action Planning of Kendal MDG's was also the parameter for the policymaker to systematically reach and gave a positive contribution to the MDG's target. One of the ways in reaching MDG's was by cooperating with Aisyiyah, as an Implementing 
Unit from the Health Office to implement the program of DOTS TB at Muhammadiyah-Aisyiyah Healthcare Unit. During 2005-2008, Aisyiyah became the Sub subrecipient of the Regional Health office by expanding the area and program which initially only cover the healthcare unit, to some Muhammadiyah-Aisyiyah community through the Chief of the Organization, Muballigh, and Muballighat Motivator in 31 provinces. The program also involved Muhammadiyah-Aisyiyah's Medical Academy by integrating material related to TB control and DOTS strategy in the curriculum, also providing training for teachers as the motivator in TB control around the Muhammadiyah-Aisyiyah's Education environment.

\section{Methods}

This study has used a mix-method design. Quantitative methods have been carried out to analyze the profile and root causes of the TB care policy implementation. Then qualitative methods have been used to determine the validity of data on the implementation of TB care program policies that have been obtained in quantitative methods. The approach that has been used in this research is a documentation study approach and a participatory approach.

Analysis of the TB control policy situation in Kendal Regency was carried out by analyzing the situation of TB control based on the community's right to health. Situation analysis aims to reduce the number of TB cases, pain, deaths, and recurrences, break the chain of TB transmission, increase TB cure rates, and a safer life. These targets can be achieved by collaborating between potential networks, advocacy, communication, and community empowerment. Situation analysis to identify basic problems, priorities, and broad effects by applying situation analysis methods and procedures.

Documentation studies have been carried out by analyzing several documents including: Kendal district health profile, Kendal city health office reports on the implementation of the TB Care program, and reports of sub recipient TB Care. The subjects of this study are stakeholders and policy implementers at the district level, district government agencies, sub-recipient TB Care, TB care cadres, TB patients, and Kendal district health office. Research subjects amounted to 14 people. Research subjects have been obtained through purposive sampling.

This research was conducted from February to December 2017. This research was conducted in Kendal Regency. Data collection sites have been carried out at the regent's office, and the Kendal district health office.

Profile analysis and root cause analysis have been carried out using fishbone analysis. Measuring instrument that has been used in the analysis is a fishbone chart. Health service analysis, budget support analysis, and role analysis have been carried out using qualitative methods. Data collection methods that have been done are interviews, Focus Group Discussion, and dissemination. Measuring tools that have been used in this method are interview guides and focus group discussion guides that have been compiled by the researcher.

The researcher has obtained permission from the Kendal district government to conduct a documentation study on the TB care program implementation report. Researchers provide an explanation of the objectives and benefits of research to prospective research subjects. The research subjects had signed an informed consent before the data collection process was carried out. The researcher did not include the identity of the research subject.

\section{Results}

Kendal regency is one of the 35 regencies in Central Java. The topography of Kendal is divided into three areas. The first is the mountain area in the southern part of Kendal at 0-2.579 above the sea level. The temperature is around $25^{\circ}$. The hill area is in the middle part of Kendal. Meanwhile, the coastal area is in the northern part of Kendal, which is at $0-10 \mathrm{~m}$ above the sea level with the temperature around $37^{\circ}$. Plantungan district is categorized as highland at $625 \mathrm{~m}$ above the sea level, Sukorejo district is about 524 above the sea level, and meanwhile, Weleri is the lowest district in Kendal at $4 \mathrm{~m}$ above the sea level. The highest population density is found in Weleri with 1962 people $/ \mathrm{Km}^{2}$, the second is Kendal City with 1930 people/ $\mathrm{Km}^{2}$, and the third is Cepiring district with 1709 people/ $/ \mathrm{Km}^{2}$.

The largest district in Kendal was Singorojo District $\left(11.9 \mathrm{Km}^{2}\right)$, and the second was Patean district $\left(9.27 \mathrm{Km}^{2}\right)$. On the other hand, the smallest was Rininarum $\left(2.3 \mathrm{Km}^{2}\right)$, followed by Kendal $\left(2.7 \mathrm{Km}^{2}\right)$ and Cepiring $\left(3.0 \mathrm{Km}^{2}\right)$. The highest population density was found in Weleri with 1962 people/ $\mathrm{Km}^{2}$, the second was Kendal City with 1930 people $/ \mathrm{Km}^{2}$, the third was Cepiring district with 1709 people $/ \mathrm{Km}^{2}$, and the fourth was Rowosari with 1678 people/ $/ \mathrm{Km}^{2}$.

The community ratio based on the productive age, $67.56 \%$ was in the productive age (15-64-yearsold), and $32.44 \%$ of the community was in the nonproductive age (0-14-years-old and above 65-yearsold). The highest age group, either male or female, was 15-19-years-old, followed by 25-29-years-old, and 30-34-years-old. The ratio between the productive and nonproductive community in 2012 was 48.01 . It means 100 productive people bear 48 nonproductive people. 
In terms of educational background, most of the TB patients went through elementary and secondary school. Meanwhile, for the occupation, most of them were factory laborers, small vendors, and farmers. Kendal District had numbers of health care units, including one hospital, two community health centers, and four health sub-centers with ten beds capacity. It was followed by Rowosari District with five health care units, including two community health centers and three health sub-centers with 50 beds capacity. Meanwhile, a district with the least number of health-care units was Pegandon, with only a community health center and a health sub-center.

All the districts in Kendal regency had been facilitated with health workers. Sukorejo District had 70 health workers consisted of general practitioners, dentists, nurses, midwives, sanitarians, pharmacists, nutritionists, and anesthetists. It was followed by Rowosari District with 67 health workers. Meanwhile, the least health workers were owned by Pageruyung District with only 24 health workers, minus dentist, and pharmacist.

The government's fund for Kendal Regency was fluctuating. The highest fund was received in 2010, 10 times lower in 2012, and was gained again in 2013. The local government budget for Kendal in 2013 was Rp. $2,617,500,000$ but only Rp. $2,573,203,000$ or $98.31 \%$ of the total budget was well allocated. It was allocated for Jamkesda or the regional health insurance for the health office of Kendal regency.

The policy determined to achieve the target to fight against HIVIAIDS and other transmitted diseases such as TB involved:

1. Decreasing HIVIAIDs prevalence was directed to improve the case tracking, VCT administration, monitoring high-risk groups of HIV transmission, improving stakeholders' role, especially in some districts with a high risk of HIVIAIDS transmission.

2. Decreasing pulmonary TB was directed to the improvement of CDR TB, the improvement of DOTS administer performance, improving the health environment.

Based on a survey to assess the MDGs target achievement in district and village, it was found that TB patients in Kendal were 788 cases with the highest case found at Rowosari, followed by Boja with 700 cases. The program evaluation based on Kendal regency indicators in 2013 from the regional health office found the following details. CDR at Rowosari community healthcare was $74.7 \%$, the examined suspects were $58.6 \%, 12.7$ was AFB positive, and the AFB positive in TB patients was 34.2. Kendal community healthcare $1 \mathrm{CDR}$ at $67.4 \%$, the examined suspect was $47.8 \%, 14.1$ was AFB positive, and the AFB positive in TB patients was 26.8 . Kendal community healthcare 2 CDR $63.1 \%$, the examined suspect was $74.7 \%, 8.5$ was AFB positive, and the AFB positive in TB patients was 94.9. Boja community health care 2 CDR $59.1 \%$, the examined suspect $72.8 \%, 8.1$ was AFB positive, and the AFB positive in TB patients was 58.6.

Aisyiyah's TB care data were started in 2012 by the finding of suspects and AFB positive. Meanwhile, the Aisyiyah's TB care agenda was TB Day, which was administered from March 24 to May 24,2014. Theactivities including health counseling, TB corner, roof installation, UPGK or Family Nutrition Improvement Effort, talk show, tracking, and mass mobilization: Green walk, early TB prevention, public charity, and Friday preaching. Kendal was listed on number 10 with seven new AIDS cases. Kendal regency was HIV AIDS transmission potential. Based on the survey, most HIV AIDS patients were found in Gemuh district with seven cases. Meanwhile, the highest number of referred children and pregnant mothers as HIV AIDS suspects was found in Rowosari District. Based on the Condom Demand data, the use of condoms in a high-risk area in 2011 was $70 \%$. MDGs target in 2015 was improved. Therefore, it was expected that Kendal could accomplish the MDGs target in 2015. The community proportion between 15 and 24-years-old had a comprehensive knowledge of HIV and AIDS. People with HIV AIDS knowledge in 2011 was $34.54 \%$. This condition was improved as in 2010; the level of knowledge was only $18.1 \%$. The proportion of advanced HIV infected had access to antiretroviral drugs. Kendal residents with HIV AIDS with antiretroviral medication were $21.74 \%$ in 2011 . This condition was decreased compared to 2010 condition with $21.95 \%$.

The finding of TB suspect in Kendal every year was improved. In 2011, there were 517 cases or $24 \%$. It was improved to 584 cases or $26 \%$ in 2012 and improved again to $50 \%$ out of 1001 cases in 2013. The finding of TB relapsed in Kendal was also improved every year. In 2011, there were 14 cases or $20 \%$, improved to 17 cases or $25 \%$ in 2012, and improved again to $55 \%$ or 38 cases in 2013 .

The finding of treatment failure in Kendal regency in 2010 was $29 \%$ or two cases. The highest percentage of treatment failure was $57 \%$ or four cases in 2011 and then decreased to $14 \%$ or one case in 2013 . The finding of TB pediatric patients in Kendal during 2010 was 55\% or 398 cases, during 2011 was $44 \%$ or 320 cases, and decreased to $1 \%$ or two cases in 2013 . The MDR-TB case was first found in 2012, and there were eight cases. Among those cases, two patients completed the treatment, two patients died, one patient dropped out of the treatment, and three patients were still in the treatment.

\section{Discussion}

The analysis of this research could be represented by the following root cause analysis. 


\section{TB, MDR-TB, and HIVIAIDS profile analysis}

The correlation of the points above could be drawn into a fishbone diagram about the transmission of TB, MDR-TB, and HIV AIDS based on the healthy concept by H. L. Bloom. The situation analysis was done using a fishbone diagram or cause and effect diagram or Ishikawa Diagram. The diagram was done to identify the probability of a problem's cause, especially when a team thought of a habit (Tague, 2005, p. 247) $[7,8]$. An action and improvement could be easily made by finding the root cause first. The fishbone diagram was very helpful in finding the root cause of a process in which many new problems could appear (Purba, 2008, para. 1-6) $[9,10]$.

The fishbone diagram would identify all the potential causes of an effect or problem and analyze the problem in a brainstorming session. The problem would be divided into some correlated categories such as human (host), agent (Mycobacterium tuberculosis), environment, procedure, local government policy, and so on. Each category had causes that needed to be elaborated in the brainstorming session.

Analysis of TB, MDR-TB, and HIVIAIDS transmission profile:

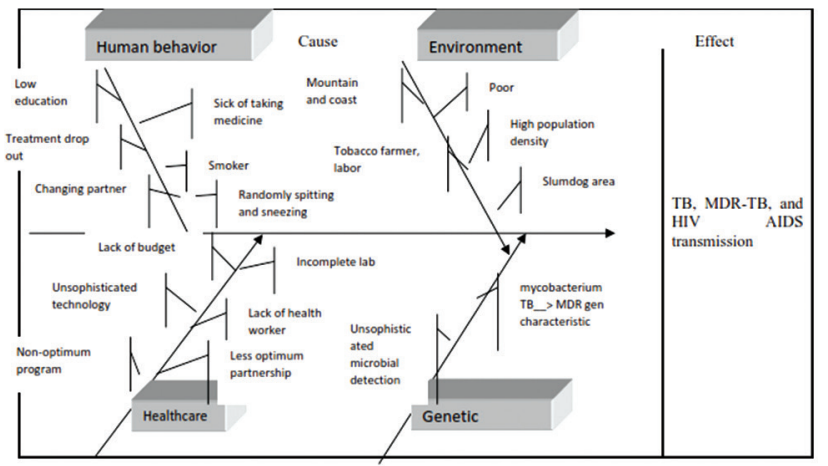

According to $\mathrm{HL}$ Bloom, there are four main factors related to the community's health degree. Those four factors are the determinant factor related to health problems. The first factor is a lifestyle. It is related to the patient's style, such as the reluctance to visit the doctor, changing partner, sick of taking medicine, smoking habit, randomly spitting and sneezing, changing the health-care unit. Those factors are supported by the low educational background and the minimum access to adequate information [11].

In term of the environment factor (social, economy, politic, and culture) in Kendal, which consists of the mountain and coastal area, leads to the difficulty in accessing health-care unit. Besides, the main occupation as labor with low income and tobacco farmer, which is potential to addictive elements exposure from the plant, unhealthy living area with minimum ventilation, lighting, and cleanliness, high-density population add the list of high-risk transmission factors [12].
The health-care factor (the scope and quality) was related to the lack budget from the government, the unsophisticated technology, the lack of health worker, not enough laboratory facility, and less optimum partnership. The genetic factor was related to finding the potential causes through brainstorming, analyzing, and agreeing with the most potential causes.

\section{Health-care analysis}

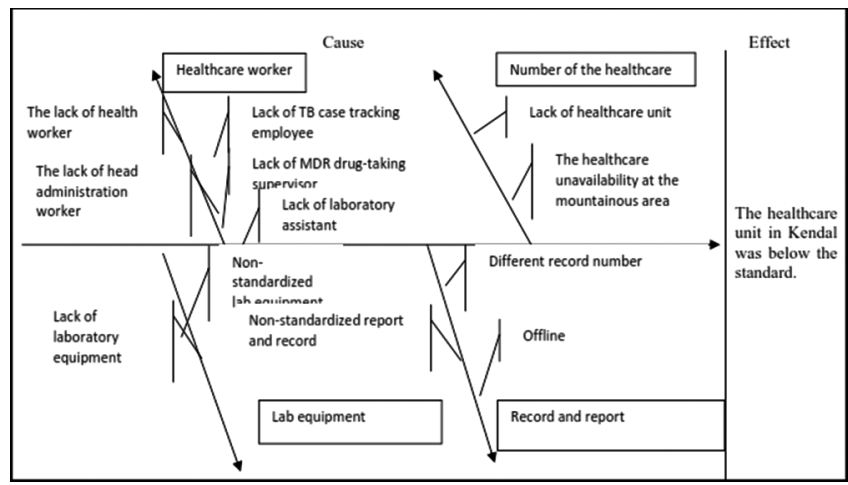

The uneven distribution of health-care unit and the lack of health workers lead to the less optimum case tracking, lack of drug-taking supervisor which cause the lack of drug-taking supervision, and the most important. It causes a rise in the MDR-TB case. The mountain and coastal areas were also inaccessible to the health-care unit, so that those areas needed more healthcare and health workers $[13,14]$.

\section{The analysis of budget support}

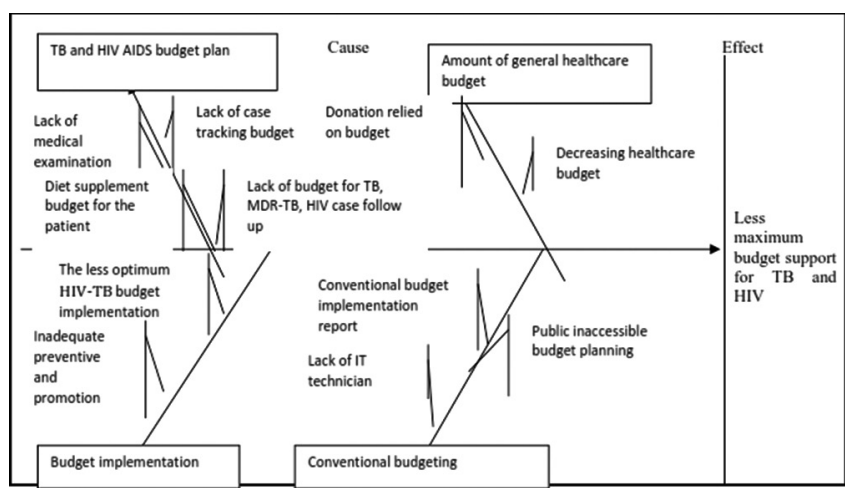

Kendal regency was the potential to poverty, as the highest age group in Kendal was the productive age, and the TB cases were mostly found within the productive age. Poverty led to the inability to build a healthy living and provide high quality and healthy diet. It could affect people's immunity and transformed the non-virulent $M$. tuberculosis to be a virulent $M$. tuberculosis. On the other hand, the health condition of a person could also affect the economic condition [15]. 


\section{Human resource empowering}

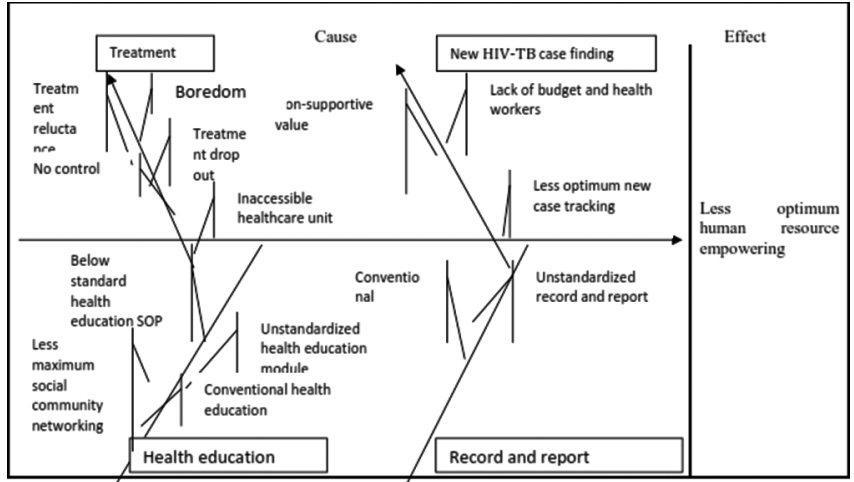

The new case tracking was below the expectation. The mountain and coastal areas were inaccessible by the health workers. The more health worker to conduct the new case tracking was required. There was a value believed by Kendal community that being ill means that they cannot properly perform their activities. Therefore, being ill means, they cannot do any activity. If someone did not show any symptom, it means that they did not need any medical treatment [16]. However, M. tuberculosis has a long incubation period in the lungs. It needs 3 weeks for the germ infection to the lung complication. Therefore, it frequently found that patient comes to the healthcare unit when the infection worsens and needs more complex treatment. And during the incubation period, the germ might also infect other family members, as it is an airborne disease (droplet infection). The long-term treatment may lead the patient into boredom, the checkup reluctance, and the lack of a drug-taking supervisor could stimulate the MDR-TB [17].

\section{Less maximum patient and community knowledge improvement}

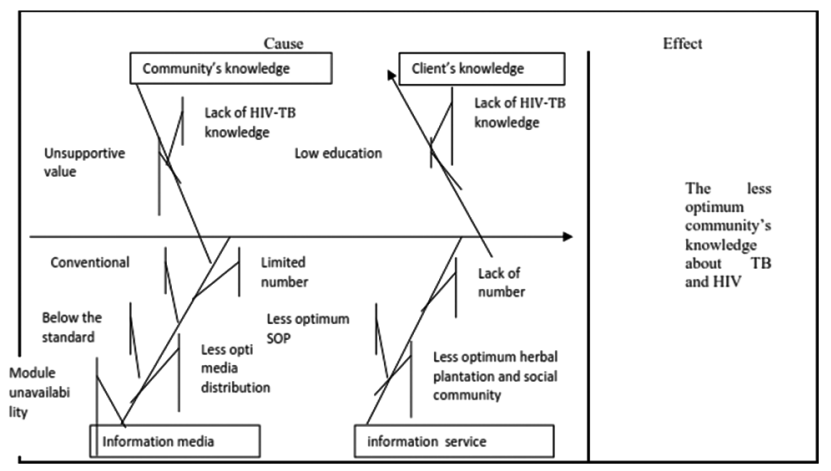

The low educational background and economic condition lead to less optimum information absorption.

\section{Conclusion}

TB Situation analysis of Kendal Regency in 2014 was done using technical situation analysis of primary and secondary data, field survey, confirmation, budgeting, and matriculation of the multivariate factors which aimed to: Improving TB recovery rate, decreasing and cutting off the TB transmission, decreasing number of illness, and morbidity. From the analysis, some conclusions were obtained as listed below:

\section{The problem in TB situation analysis}

a. The topography of Kendal, which is located both in the mountainous and coastal areas, is an indicator of high risked TB transmission and the growth of TB germs due to the high humidity with minimum sun exposure.

b. The poverty in Kendal Regency might be caused by most of the population, and also the most TB case was within the productive age. Poverty made people difficult to provide healthy living areas, also a healthy and nutritious diet, which resulted in a weak immune system. The low immune system transformed the non-virulent $M$. tuberculosis to be a virulent $M$. tuberculosis. On the other hand, the health condition of a person could also affect the economic condition.

c. The high population density led to the difficulty in finding a job. Therefore, they chose to work abroad. The further effect of this phenomenon was when the wife decided to work abroad. The husband was highly likely to engage with commercial sex activity. This activity directly contributed to the increase of HIVIAIDS and HIV-TB case number.

d. In 2014, it was found that most of Kendal regency community only went through elementary and middle school. It meant that they had a low educational background. This is a predisposing factor that worsens the absorption and comprehension of information. People with low educational backgrounds tended to difficult in accepting change and reformation. Therefore, misleading information about TB frequently happened. It could also affect the case of treatment drop out.

e. From the demography status, it was found that most of Kendal Regency communities worked as a tobacco farmer. Tobacco is a predisposing factor that is strongly related to some diseases due to the long term nicotine exposure. It could lead to pulmonary degradation and support the growth of $M$. tuberculosis.

f. A value believed by Kendal community that being ill means that they cannot properly perform their activities. Therefore, being ill means, they cannot do any activity. If someone did not show any symptoms, it means that they did not need any medical treatment. However, M. tuberculosis has a long incubation period in the lungs. It needs 3 weeks for the germ infection to the lung complication. Therefore, it frequently found that patient comes to the healthcare unit when the 
infection worsens and needs more complex treatment. And during the incubation period, the germ might also infect other family members, as it is an airborne disease (droplet infection).

g. A district with adequate healthcare and human resource could rapidly track the TB patient and increase the percentage of CDR, TB suspects, and AFB (+). It could also enable immediate treatment to lower the risk of transmission to the other family member.

h. The participation of the health-care unit in improving the community's knowledge could rapidly track the TB patient and increase the percentage of CDR, TB suspects, and AFB (+). It could also enable immediate treatment to lower the risk of transmission to the other family member.

i. The budget support in the form of $A P B D$ or local government budget and $B O K$ or Health Operational Funds to stimulate new TB case tracking and increase the percentage of CDR, TB suspects, and AFB (+). It could also enable immediate treatment to lower the risk of transmission to the other family member, stimulate the TB patient to actively go to the treatment, and improve nutrition intake for MDR-TB, which aimed the decrease of relapse and MDR-TB case number.

\section{Recommendation for TB advocacy action}

Based on the Kendal Regency TB situation analysis in 2014, the advocacy recommendation that could be carried soon and relevant to the Regional Working Unit of Health Office's action plan were:

a. Workshop to arrange healthcare standards, including the types of health care such as promotive, preventive, curative, and rehabilitative healthcare.

b. The fair composition of health workers and human resources for all health-care units in Kendal regency such as general practitioner, dentist, nurse, midwife, analyst, nutritionist, sanitarian, and pharmacist.

c. Increase the number of infectious disease eradication assistants, especially for TB eradication.

d. The urgency to start online recording and reporting to ease the access.

e. TB counseling through social media which is accessible for the community.

f. The cooperation with nearby organizations or corporations to declare the TB care program.

\section{Policy support}

The basic aspect of the situation analysis and advocacy action recommendation was the policy to support TB control programs from the stakeholder in Kendal Regency and Central Java. With the great support and planning toward the proposed programs, it is expected that the community could well improve the knowledge, behavior, and attitude to live healthily, keep cleanliness, and provide a nutritious diet. The collaboration is needed to succeed. The action within the network consists of stakeholders, community, government, and institution in preventing and coping TB cases, with also innovating for the TB treatment. The support is also needed to upgrade the competence and skill of health workers and TB counselors to give better counseling to TB, MDR-TB, and HIV-TB patients, improve sympathetic interpersonal communication to build a positive mentality of patients, and provide sufficient treatment for pediatric TB in Kendal Regency.

\section{Acknowledgments}

The authors would like to thanks to Kendal public health office, Kendal city government, and global fund who took part in this study.

\section{References}

1. Azizi Z. Pandemi Multi Drug Resisten Tuberculosis; 2012 Avaialble from: http://www.zasyah-azizi.blogspot.com/2012/04/ pandemi-multi-drug-resistent. [Last accessed on 2014 Jun 02].

2. Badri A. Beberapa Faktor Yang Berhubungan Dengan Kinerja Petugas Laboratorium Dalam Penentuan Penderita TB Paru di Kabupaten Kerinci; 2006.

3. Bappeda Kota Semarang dan BPS Kota Semarang. Semarang Dalam Angka. Semarang: Bappeda Kota Semarang dan BPS Kota Semarang; 2012. https://doi.org/10.18326/infsl3. v6i2.393-416

4. Departemen Kesehatan. Pedoman Nasional Penanggulangan Tuberkulosis. $2^{\text {nd }}$ ed. Jakarta: Depkes RI; 2007.

5. Depertemen Kesehatan. Petunjuk Teknis Penatalaksanaan Pasien TB-MDR. Jakarta: Depkes RI; 2009.

6. Kementerian Kesehatan. Direktorat Jendral Pengendalian Penyakit dan Penyehatan Lingkungan Kementrian. Indonesia: Kementerian Kesehatan; 2014. https://doi.org/10.22236/jmbp. v1i1.5708

7. Kesehatan Republik Indonesia. Petunjuk Teknis Tata Laksana Klinis Koinfeksi TB-HIV. Jakarta: Depkes RI; 2012.

8. Dinkes Provinsi Jawa Tengah. Rencana Strategi Dinas Kesehatan Provinsi Jawa Tengah. Semarang, Indonesia: Dinkes Provinsi Jawa Tengah; 2010. https://doi.org/10.36762/ jurnaljateng.v17i2.793.

9. Dinkes Provinsi Jawa Tengah. Buku Profil Kesehatan Provinsi Jawa Tengah Tahun. Semarang, Indonesia: Dinkes Provinsi Jawa Tengah; 2013. https://doi.org/10.36762/litbangjateng. v17i1.759

10. Dinkes Provinsi Jawa Tengah. Buku Saku Kesehatan Triwulan 3 Tahun. Semarang, Indonesia: Dinkes Provinsi Jawa Tengah; 2013. https://doi.org/10.36762/litbangjateng.v17i1.759 
11. Kementerian Kesehatan Republik Indonesia. Profil Data Kesehatan Indonesia Tahun 2011. Jakarta: Kementerian Kesehatan Republik Indonesia; 2012. https://doi.org/10.7454/ jki.v19i3.469

12. Pengendalian Penyakit dan Penyehatan Lingkungan. Strategi Nasionalpengendalian TB di Indonesia 2010-2014; 2011. Available from: http://www.pppl.depkes.go.id/_asset/_regulasi/ STRANAS_TB.pdf. [Last accessed on 14 Jan 2021].

13. Syafei and Kunanto. Kinerja Petugas Paru Puskesmas di Kota Jambi. Syafei and Kunanto; 2006.

14. World Health Organization. Tuberculosis (TB). Geneva: World
Health Organization; 2012. Available from: http://www.who.int/ tb/en. [Last accessed on 14 Jan 2021].

15. World Health Organization. Metrics: Disability-Adjusted Life Year (Daly). Geneva: World Health Organization; 2012. Available from: http://www.who.int/healthinfo/global_burden_disease/ metrics_daly/en. https://doi.org/10.1016/b9778-0-12-4095489.11699-9. [Last accessed on 14 Jan 2021].

16. World Health Organization. Global TuberCulosis Repport 2013. Prancis, Geneva: World Health Organization; 2013.

17. World Health Organization. Kebijakan Sementara Kegiatan TB-HIV. Switzerland, Geneva: World Health Organization; 2004. 